\title{
The investigation of an arbovirus encephalitis
}

\author{
H. E. WeBB \\ St Thomas's Hospital, London, S.E.1
}

\begin{abstract}
Summary
A definition of an arbovirus and a broad idea of the groups and the numbers isolated and causing human infection are given. The small incidence of clinical disease compared with overall infection rates is stressed. The conditions for the successful survival of arboviruses is outlined. The investigation of the illness and origin of infection is described. The role of viral antibody in the development of encephalitis and the use of cortisone in treatment is discussed. The over-wintering of arboviruses and their capacity for latency is considered in relationship to the perpetuation of virus and the pathogenic effects on the hosts involved.
\end{abstract}

\section{Introduction}

An arbovirus is a virus, which in nature, can infect blood-sucking arthropods by their ingestion of infected vertebrate blood. Viruses which are only mechanically transmitted by arthropods such as myxomatosis and avian pox virus are excluded from this group. The virus must be able to invade the arthropod's tissue, multiply and be transmitted in their saliva by bite to susceptible vertebrates. At the present moment there are some 200-250 known arboviruses of which some fifty-six are known to cause human disease. These belong in fifteen distinct antigenic groups with several viruses ungrouped. Week by week these figures change and up-to-date information on all the arthropod-borne viruses can be got from the Catalogue of Arthropod-Borne Viruses of the World (1968). The main groups are A, B and $C$, of which group $A$ and $B$ provide the most recognizable human illnesses and certainly the viruses which are more commonly involved in epidemics in which encephalitis cases are seen (see Tables 1 and 2). The groups are able to be divided in such a way because of the work of Casals \&

TABLE 1. Group A

\begin{tabular}{|c|c|c|c|c|c|c|}
\hline \multirow[b]{2}{*}{ Virus } & \multicolumn{6}{|l|}{ Isolations } \\
\hline & Areas of the World & Man & Rodents & Birds & Other & $\begin{array}{l}\text { Mosqui- } \\
\text { toes }\end{array}$ \\
\hline $\begin{array}{l}\text { Aura } \\
\text { Bebau }\end{array}$ & $\begin{array}{l}\text { Belem, Brazil } \\
\text { Malaya }\end{array}$ & & & & & + \\
\hline *Chikungunya & $\begin{array}{l}\text { Tanganyika, Uganda, South Africa, Congo, Senegal, } \\
\text { Nigeria, Thailand, Cambodia, India }\end{array}$ & + & & & + & $\begin{array}{l}+ \\
+\end{array}$ \\
\hline †EEE & $\begin{array}{l}\text { U.S.A., Dominican Republic, Jamaica, Trinidad, Brazil, } \\
\text { British Guiana, Panama, Argentina }\end{array}$ & + & + & + & + & + \\
\hline Getah & Malaya, Japan, Australia & & & & & + \\
\hline Highlands $\mathbf{J}$. & U.S.A. & & + & + & & + \\
\hline $\begin{array}{l}\text { Mayaro } \\
\text { Middelburg }\end{array}$ & $\begin{array}{l}\text { Trinidad, Belem, Bolivia, Panama, Surinam } \\
\text { South Africa }\end{array}$ & + & & & & + \\
\hline *Mucambo & Belem, Trinidad, Surinam & + & + & + & + & + \\
\hline Ndumu & South Africa & & & & & + \\
\hline O'nyong-nyong & Uganda, Kenya & + & & & & + \\
\hline Pixuna & Belem & & + & & & + \\
\hline Ross River & Australia & & & & & + \\
\hline Semliki & Uganda, Cameroons, Mozambique & & & & & + \\
\hline Sindbis & $\begin{array}{l}\text { Egypt, Uganda, South Africa, India, Philippines, } \\
\text { Australia }\end{array}$ & + & & + & & + \\
\hline Una & Belem, Trinidad, Colombia, Panama & & & & & + \\
\hline †VEE & $\begin{array}{l}\text { Venezuela, Trinidad, Colombia, Equador, Panama, } \\
\text { Mexico, U.S.A. }\end{array}$ & + & + & + & + & + \\
\hline $\begin{array}{l}\text { Whataroa } \\
\text { †WEE } \\
\text { Y } 6233\end{array}$ & $\begin{array}{l}\text { New Zealand } \\
\text { U.S.A., Brazil, Argentina, British Guiana, Canada } \\
\text { U.S.S.R. }\end{array}$ & + & + & + & + & $\begin{array}{l}+ \\
+ \\
+\end{array}$ \\
\hline
\end{tabular}

* Naturally occurring cases of encephalitis are seen.

$\dagger$ Epidemics of encephalitis. 
TABle 2. Group B

\begin{tabular}{|c|c|c|c|c|c|c|c|}
\hline \multirow[b]{2}{*}{ Virus } & \multicolumn{7}{|c|}{ Isolations } \\
\hline & Areas of the World & Man & Rodents & Birds & Other & $\begin{array}{l}\text { Mosqui- } \\
\text { toes }\end{array}$ & Ticks \\
\hline \multicolumn{8}{|l|}{ Mosquito-borne } \\
\hline Banzi H 336 & South Africa & + & & & & + & \\
\hline Bussuquara & Belem, Colombia, Panama & + & + & & & + & \\
\hline Dengue type 1 & $\begin{array}{l}\text { Hawaii, New Guinea, Japan, India, } \\
\text { Malaya, Thailand, Cambodia, Singa- } \\
\text { pore }\end{array}$ & + & & & & + & \\
\hline Dengue type 2 & $\begin{array}{l}\text { New Guinea, India, Thailand, Trinidad, } \\
\text { Philippines, Vietnam, Malaya, Singa- } \\
\text { pore }\end{array}$ & + & & & & + & \\
\hline Dengue type 3 & $\begin{array}{l}\text { Philippines, Thailand, East Pakistan, } \\
\text { Malaya, Singapore, Puerto Rico }\end{array}$ & + & & & & + & \\
\hline Dengue type 4 & $\begin{array}{l}\text { Philippines, Thailand, India, Malaya, } \\
\text { Cambodia }\end{array}$ & + & & & & + & \\
\hline Edge Hill & Australia & & & & & + & \\
\hline *Ilheus & $\begin{array}{l}\text { Brazil, Trinidad, Honduras, Panama, } \\
\text { Guatemala, Colombia }\end{array}$ & + & & + & & + & \\
\hline Israel, Turkey ME & Israel & & & + & & & \\
\hline †Japanese B & $\begin{array}{l}\text { Japan, Korea, China, Thailand, Malaya, } \\
\text { Taiwan, Singapore }\end{array}$ & + & & + & + & & \\
\hline Kokobera & Australia & & & & & + & \\
\hline Kunjin & Australia & + & & & & + & \\
\hline †Murray Valley & Australia, New Guinea & + & & & & + & \\
\hline Ntaya & Uganda, Ethiopia & & & & & + & \\
\hline †St Louis & U.S.A., Trinidad, Panama, Belem & + & & + & & + & \\
\hline Spondweni & South Africa, Nigeria & + & & & & + & \\
\hline Stratford & Australia & & & & & + & \\
\hline Tembusa & Malaya, Sarawak & & & & & + & \\
\hline Uganda $S$. & Uganda, Nigeria & & + & & & + & \\
\hline Usutu & South Africa, Uganda & & & & & + & \\
\hline Wesselsbron & South Africa & + & & & + & + & \\
\hline *West Nile & $\begin{array}{l}\text { Uganda, Egypt, South Africa, Congo, } \\
\text { Israel, France, U.S.S.R., India, } \\
\text { Nigeria }\end{array}$ & + & & + & & + & \\
\hline *Yellow Fever & $\begin{array}{l}\text { Africa, South and Central America, } \\
\text { Trinidad }\end{array}$ & + & & & + & + & \\
\hline Zika & Uganda & + & & & & + & \\
\hline \multicolumn{8}{|l|}{ Tick-borne } \\
\hline *Powassan & Canada, U.S.A. & + & + & + & + & & + \\
\hline $\begin{array}{l}\text { *Louping-ill } \\
\text { tTick-borne enceph. }\end{array}$ & Great Britain & + & + & + & + & & + \\
\hline Central European & $\begin{array}{l}\text { Sweden, Finland, Poland, Czechoslo- } \\
\text { vakia, Hungary, Yugoslavia, Austria, }\end{array}$ & + & + & + & + & & $\dot{+}$ \\
\hline Far Eastern (RSSE) & U.S.S.R. & & & & + & & + \\
\hline \multicolumn{8}{|l|}{ Omsk. hem. fever } \\
\hline I & U.S.S.R. & + & & & & & + \\
\hline II & U.S.S.R. & + & & & & & + \\
\hline *Negishi & Japan & + & & & & & \\
\hline $\begin{array}{l}\text { *Kyasanur forest } \\
\text { Langat }\end{array}$ & $\begin{array}{l}\text { India } \\
\text { Malaya }\end{array}$ & + & + & + & + & & $\begin{array}{l}+ \\
+\end{array}$ \\
\hline
\end{tabular}

* Naturally occurring cases of encephalitis are seen.

† Epidemics of encephalitis.

Brown (1954). Viruses that cross-reacted in one or several serological tests were considered to form an antigenic group (Casals, 1957). These original studies were further amplified by Casals (1963). As can be seen from Tables 1 and 2 the chief vectors are mosquitoes and ticks. In the case of ticks, infection can take place at any stage of development, larva, nymph or adult. Hurlbut \& Thomas (1960) infected other arthropods, cockroach, grasshopper, bedbug, bug, beetle, moth, housefly and soft tick with a range of arboviruses and only the cockroach failed to support multiplication of any of them. Alifanov et al. (1961) reported transmission of Omsk haemorrhagic fever by mites (Laelaptidae). It is of interest 
to note that Central European tick-borne encephalitis can be transmitted to humans by goats' milk as well as tick bite.

The number of clinical cases of encephalitis seen in an epidemic from an arbovirus infection will represent only a fraction of the total number of people infected. That many others do in fact have virus in their central nervous system (CNS) during the acute infection without clinical disease is likely (Webb et al., 1968b) and may account for clinical disturbances at a later date such as post-encephalitic parkinsonism, dementia and other psychiatric disturbances. It is also important to understand that man becomes infected only incidentally when he lives in or visits a place in which the virus activity in the blood of certain of the vertebrate hosts of the area is or becomes of sufficiently high titre to infect the local arthropod species which may then bite and infect him. This being the case the physician, who is interested in prevention of these serious illnesses for which there is no specific cure, will realize that the control of the disease will depend on changing the conditions which allow the virus to thrive in nature. It is, therefore, very important to have an understanding of the factors which play a part in an arbovirus zoonosis.

In the British Isles arbovirus infections are rare because the conditions for transmission are not right. Smith (1964a) goes into this problem in great detail and states that the frequency of successful transmission between maintenance populations of animals and between them and man depends on the following factors:

\section{Duration of infectivity}

Duration of infectivity is the duration of viraemia in vertebrate hosts which exceeds that necessary for infection of the arthropod species concerned.

\section{Duration of incubation period}

Virus multiplication is temperature-dependent and the temperature of arthropod tissues is only slightly above that of the environment. At low temperature virus may persist in a mosquito but sufficient multiplication may never be achieved for infectivity. However, there can be dramatic shortening of incubation by short periods of high temperature (Bates \& Roca-Garcia, 1946). Temperature is not so important with tick-borne viruses because the intervals between feeding are likely to be longer than the incubation period.

\section{Virus stability}

In the arthropod-borne zoonosis the virus is maintained in an arthropod between one vertebrate and the next.

\section{Population factors}

This can be most clearly seen in rodents which tend to live within a defined area (Harrison, 1958). For an infection to persist in a restricted area there must be continuous replenishment of the population of susceptible vertebrates.

\section{Climate and microclimate}

Low temperatures reduce biting and breeding activity of mosquitoes (Bonne-Wepster \& Brug, 1932; Walker et al., 1942). The biting activity of ticks is also affected by temperature-Smorodintsev (1958) showed that Ixodes persulcatus, the vector of Russian spring-summer encephalitis (RSSE) starts biting about $3-4^{\circ} \mathrm{C}$, reaches a maximum about $10-12^{\circ} \mathrm{C}$ and decreases above $18^{\circ} \mathrm{C}$ The main effect of humidity is on the microclimate of the resting places of the arthropods. High humidity increases a mosquito's life-span. Similarly in ticks the humidity requirement of different species determines their distribution and thus that of the infections they transmit. In the British Isles Ixodes ricinus, the transmitter of louping ill, requires a very high humidity for its development which it finds in thick grass and rushes on poorly drained land. In Europe the right conditions prevail on the floor of deciduous and mixed forests where it transmits encephalitis to man. Smith (1962) shows how the distribution of these infections is precisely that of the appropriate habitat.

\section{Animal behaviour}

The movement of animals by day or night, at ground level or in the canopy of the forest must coincide in time and place with the species of mosquito or tick which is infected with virus. Nocturnal mammals will, therefore, not be infected by day-biting mosquitoes and vice versa. The migration of small mammals is possibly very important in bringing disease to human populations as Gajdusek (1953) has shown in his studies on small mammals, carrying ticks infected with Crimean haemorrhagic fever. The migration of birds is also of great import. Hoogstraal \& Kaiser (1961) and Hoogstraal et al. (1961) have shown how tick species can be transferred between southern Russia and north-eastern Africa.

\section{Human behaviour}

Man can move from one situation to another with the greatest of ease from dry hot climates to wet humid climates, from sparse vegetation to areas of thick vegetation, from areas with a small mammal and domestic animal population to a high one and so forth. He can alter his conditions by buildings, dams and reservoirs or draining areas, by planting forests or cutting them down and many other ways. It is his capacity to do 
this and then alter the vertebrate population, the arthropod population and the local climatic conditions which may produce situations ideal for the introduction of an arthropod-borne infection into a non-immune population and thus cause an epidemic.

\section{Host susceptibility}

The number of successful transmissions of virus is proportional to the host population which is nonimmune. Macnamara (1955) showed that before four Nigerian epidemics of yellow fever $20-30 \%$ of the human population had antibody and $46-64 \%$ after the epidemics. Circulating antibody prevents viraemia, and, therefore, rules out the re-infection of biting arthropods. An excellent review article by Smith (1964a) is available which deals fully with factors in transmission of virus infections from animals to man and another by the same author (Smith, 1964b) on the host-parasite relationships in invertebrate hosts.

\section{Clinical syndrome}

The encephalitic phase of a specific arbovirus infection has no particular clinical symptomatology or signs which will distinguish it for certain from any other virus encephalitis. The epidemiological situation will give a lead as to which may be the infecting virus and this can only be confirmed by proper laboratory studies. The most important point to appreciate is that the encephalitic stage represents the second phase of the disease process (see Fig. 1). In most infections the only illness experienced is that associated with the first phase. Frequently infection takes place without any symptoms at all. The onset of the second phase, the phase of CNS involvement, can often be very dramatic and for reasons already mentioned appear to the clinical observer as the start of the disease. But if the clinical history is carefully taken it is usual to find some minor upset starting up to 2 or 3 weeks previously from which the patient has recovered. The appreciation of this biphasic pattern in viral illnesses is very important in understanding the pathogenesis of the clinical problems encountered. The duration of the first phase, the interval and the second phase will vary from infection to infection and from individual to individual. This biphasic nature can be seen in poliomyelitis (Horstmann, McCollum \& Mascola, 1954) and in many arbovirus infections (Webb \& Lakshmana Rao, 1961 ; Webb et al., 1966). It can be studied experimentally in primates (Gleiser et al., 1961; Webb \& Chatterjea, 1962; Webb \& Burston, 1966).

The first phase is characterized by one or several common general symptoms such as fever, malaise, myalgia, sore throat, tender glands and diarrhoea. This is usually associated with a leucopenia and sometimes a pancytopenia. The second phase presents with three different types of emphasis. The mildest is just a very severe headache with vomiting 8 and fever. This may go on to the second type having marked meningism and irritability but without localizing signs. Lastly, frank encephalitis may? develop with or without meningism but with many different neurological signs. This second phase is

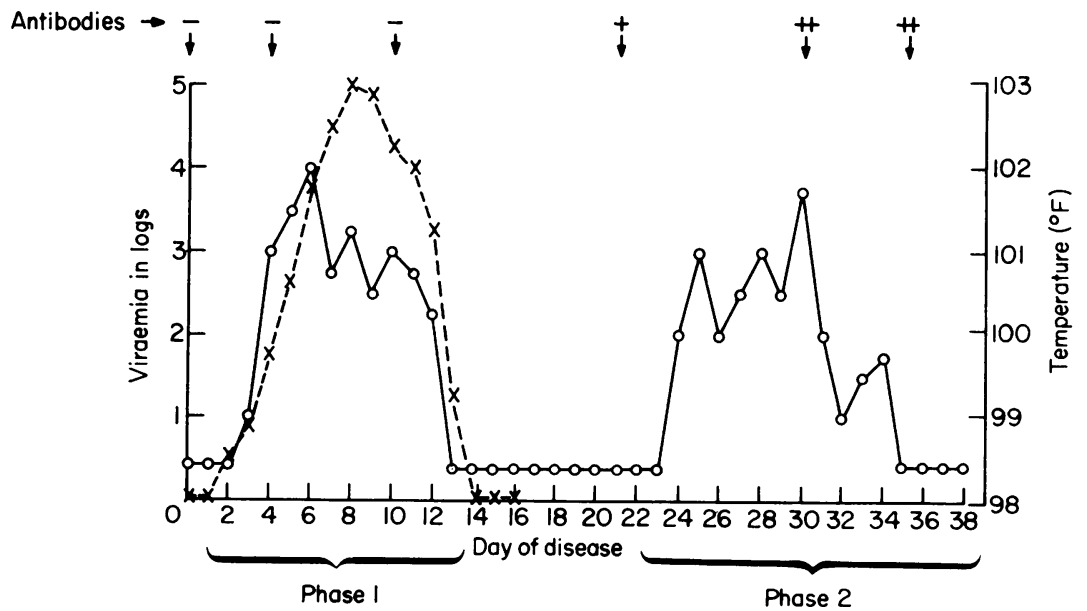

FIG. 1. Clinical and virological findings related to day of disease. Phase 1: fever, headache, myalgia, cough, diarrhoea. Phase 2: CNS disturbance. $O$, Temperature; $\times$, viraemia. This figure has been constructed from studying infections of humans in the field by one of the RSSE virus group, KFD (Webb \& Lakshmana Rao, 1961), and also of patients being treated in hospital for malignant disease with this virus and the closely related Langat virus (Webb et al., 1966). (This figure used in Modern Trends in Neurology, 4, 1967, is printed by kind permission of Butterworths.) 
often associated with a leucocytosis. In the severe cases and particularly in children focal epileptic fits, cranial nerve palsies, hemi- and diplegias, coarse tremors, papilloedema, deep coma and death may occur. Patients occasionally may present with an acute psychosis and particular care should be taken over this sort of case in the tropics if there is an associated fever: an encephalitic cause of the illness must be excluded. RSSE sometimes produces lower motor neurone paralysis affecting particularly the cervical enlargement and could be mistaken for poliomyelitis. The important point to realize is that one or many of the symptoms and signs in combination may occur and this indicates that in each case however mild, the CNS, both brain and spinal cord, is infected with virus and there is sufficient reaction to this to produce symptoms. The heavier the infection the more likely there is to be serious CNS damage. Examination of the cerebrospinal fluid (CSF) at the beginning of the acute stage characteristically shows an increase in cells, mostly lymphocytes, and a raised protein. Over 1000 cells/ $\mathrm{mm}^{3}$ is unusual as is a protein over $150 \mathrm{mg} / 100 \mathrm{ml}$. Occasionally polymorphs may predominate in the early specimens but the sugar content will be normal or represent the blood sugar. Occasionally the first CSF is normal, particularly if taken very early after the onset of CNS symptoms. Abnormal CSFs may persist for a long time and the amount of protein may rise out of proportion to the cells, i.e. $200 \mathrm{mg} / 100 \mathrm{ml}$ with no cells. The $\gamma$-globulins may also be raised and abnormalities may persist for at least a year (Webb et al., 1968a). This should not affect the patient's time of return to work, which should be judged simply on his clinical state.

\section{The investigation}

An arbovirus infection will be suspected when cases of encephalitis are occurring in a group of people who live or work in conditions in which they are coming into contact with a large population of arthropods and a range of vertebrate hosts both domestic and wild which are likely to be able to support an arthropod-borne virus. Such an investigation to be successful requires team-work and the team should consist of a clinician, a virologist and an entomologist.

An obvious lead may be given to the field team sucn as in the initial investigations into the Kyasanur forest disease (KFD) epidemic when the villagers associated their illnesses with monkeys dying in the forest (Work \& Trapido, 1957). If this is not the case then the investigation should proceed on three lines.

(1) The study of the human illnesses with a serological survey of the local population who may or may not have suffered an illness.

(2) Trapping and identification of the arthopods.
(3) The trapping and identification of the vertebrate hosts both mammals and birds in the vicinity, followed by serological studies on their blood and the ectoparasites which are infecting them.

In each case the object of the study will be to relate any virus isolated or viral antibodies present in the human cases to viruses isolated from mosquitoes and/or ticks and vertebrates. In the latter case the study of viral antibodies present in their blood will also be very important.

\section{The human illness}

At least $20 \mathrm{ml}$ of blood should be obtained from those who are sick as early in the illness as possible. This will be divided into two parts. A small amount should be taken for virus isolation and this part must be stored as quickly as possible and at the coldest temperature available, preferably $-65^{\circ} \mathrm{C}$. The second portion should be allowed to clot and the maximum amount of serum extracted and stored at $-20^{\circ} \mathrm{C}$ if possible to test for virus antibodies. A second large specimen of blood should be taken 3-4 weeks later for more serum so that any rise of antibodies can be detected. The patient with encephalitis may only be seen for the first time in the encephalitic stage which is the second phase of the illness. At this time antibodies in the blood are already raised and, therefore, it may not be possible to show a further four-fold rise in antibodies in a later specimen. In these cases it is vital to keep the first CSF for measuring antibody which rises considerably later in this medium (Webb et al., 1966; Webb et al., 1968a). A second CSF specimen should be taken 3-4 weeks later when a four-fold rise in antibody may well have taken place thus determining for certain the relationship of the disease to a specific virus. The patient, apart from the normal clinical examination, should be examined for the presence of arthropod bites and particularly for ticks which may still be feeding. Any found should be kept carefully for identification and virus isolation. If by any chance a patient should die, small amounts of each organ including brain and spinal cord and a large amount of blood should be taken as soon as possible after death and put at the lowest temperature available (preferably $-65^{\circ} \mathrm{C}$ ) for future attempts at virus isolation and in the case of serum, for antibody studies. If no very cold temperatures are available it is worth while to store the organ samples in $\mathrm{pH} 7.4$ buffered $50 \%$ glycerol saline at $4{ }^{\circ} \mathrm{C}$ while they are being shipped as quickly as possible to a centre where ideal conditions for storage are available. The sooner material stored in glycerol is processed the better.

Blood must also be collected for serum from a representative cross-section of all age-groups and of 
both sexes in the area so that this too can be assessed for the presence of virus antibody.

\section{The trapping and identification of arthropods}

This will be the special responsibility of the entomologist.

Mosquitoes. These must be collected from in and around the places of habitation and places of work both at night and during the day. Particular attention should be paid to sites of mosquito breeding, i.e. all water traps and areas of still water. Both human and different animal baits may be used for enlarging collections both during the day and night, as the type of mosquito biting will vary according to the time. It may be necessary, in jungle conditions, to collect mosquitoes at various heights, as the canopy of the jungle is likely to have a different fauna of mosquitoes compared with that at ground level. Each mosquito must be identified individually: the number of each species, the place found and the time of day collected should be recorded. In this way an accurate record can be quickly built up of the type of mosquito most active. This fact alone may give a foresight of the virus likely to be active as certain mosquitoes are more likely to carry certain types of virus. The mosquitoes are then ground up for virus isolation, having discarded those which are engorged with a blood meal as a spurious virus may be isolated from the blood which they contain.

Ticks. These may be found on humans but should be looked for on all domestic animals and wild animals and birds caught. They will also be found on the forest floor and 'questing' on the underside of leaves of the undergrowth from where they brush off onto animals and humans. A useful method of collecting ticks is to pull across the ground flannelette onto which the ticks will adhere. A great number can be collected in this way and are easily picked off. Each tick must be identified individually and in this case the stage of development (larva, nymph or adult) must be recorded. In the case of ticks collected from vertebrates a record must be kept of the species and the place where the animal was caught. Each group of ticks should be ground up individually for virus isolation. Along with these studies must be kept a simple record of temperature, humidity and rainfall conditions, mosquitoes being likely to increase activity during wet and warm periods.

\section{The trapping and identification of vertebrates}

A large representative sample of sera for testing for viral antibodies should be obtained from all types of vertebrate, domestic and wild, present in the area. In the case of domestic animals this is a fairly simple problem and at the same time they can be examined for the presence of ectoparasites which should be collected and treated as previously. Carefully laid traps are needed for rodents and in the case of bigger $c$ animals, such as monkeys, and birds it may be $\vec{\Rightarrow}$

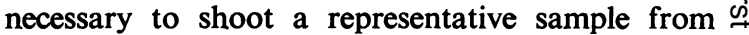
which blood and ectoparasites can be collected. At a later date it may be desirable to pass the blood and organs of various animals for virus-isolation particularly those from any animal found dying of $\Omega$ an unexplained illness.

\section{The virological investigations}

The samples collected, the virologist can get to $\vec{\omega}$ work. Approximately $94 \%$ of arboviruses flourish in mice, so all specimens for virus isolation should be passed first into baby mice. The range of animals used may have to be extended later to guinea-pigs, of hamsters, rabbits and other animals or even tissue- in culture lines. While the results of these inoculations are awaited, serum samples from the survey group $\omega$ should be tested for antibodies against representative viruses from each group A, B and C. The viruses selected for testing against should be chosen from those likely to be active in the epidemiological conditions prevailing. The simplest test to use is the haemagglutination inhibition (HI) test as described by Casals \& Brown (1954). More exact identifica⿱⺈ tion may be achieved by using the techniques described by Casals (1961), further modified by Casals (1963). These incorporate both complement fixation (CF) and neutralization tests (NT). Other techniques for CF have been described by Lennette (1964) and Sever (1962). If any virus is isolated from any of the material inoculated, then this virus should be used in HI, CF and NT tests, not only against the acute and convalescent specimens of serum and CSF from the patients seen but also in $\mathrm{HI}$ and NT tests against the survey sera from the human population and the animals bled. Many tests will need to be done to establish which virus exactly is the most active. This is why it is so important that large amounts of blood for serum specimens should be taken.

\section{Direction of modern research}

The arboviruses are easy to work with, as mice are susceptible to most of the viruses. Many produce an $\sigma$ easily titratable viraemia and antibodies which can $N$ be measured by simple NT, CF and HI techniques. N The viruses, as a group, can be recognized in known infected tissue under the electron microscope. They keep well at $-65^{\circ} \mathrm{C}$ and though laboratory infec- $\frac{\odot}{\Phi}$ tions do occur, most are not easily transmitted by $\stackrel{\circ}{\rightarrow}$ aerosol or ingestion. It is therefore possible to carry 0 out experiments on pathogenesis relating the results to virus titres in all specimens and antibody titres in 
blood and CSF. At the moment work is going on in our laboratory to discover the importance of the presence of antibody in the development of encephalitis from arbovirus infections. It is important to draw attention to Fig. 1 to note the relationship of the viraemia to the first phase of the illness, the development of antibody and the onset of the second phase. Acute CNS involvement is not seen until the viraemia is diminishing or over. The length of the interval between the end of viraemia and the onset of the encephalitic-second phase-can be very striking. I have seen cases with up to a 17-day gap between the two phases and over a week is not at all uncommon. It is therefore clear that encephalitis usually occurs at a time when considerable immunity is present in the blood. Webb \& Smith (1966) have discussed the importance of this in relation to the pathogenesis of encephalitis. Further experiments (Webb et al., 1968b, c) tend to confirm that an antigen-antibody reaction as well as the primary effect of virus on cells is very important in the production of CNS damage. Sometimes following an arbovirus infection humans die quite suddenly with a shocklike syndrome, drop of blood pressure, peripheral cyanosis, bradycardia and occasionally diarrhoea. The explanation of this is not clear. In experiments done inoculating monkeys with KFD virus (Webb \& Burston, 1966) the monkeys died at the end of a massive viraemia on the 8th to 14 th day. Twenty-four to $48 \mathrm{hr}$ before death bradycardia, hypotension and diarrhoea developed. This was at a time when antibodies were developing in the blood, and the pancytopenia recovering. The clinical syndrome seen simulated that when prostigmine is inoculated intravenously in high dosage. In view of this the autonomic nervous system was studied by standard histological techniques, but no abnormality was found. No histo-chemical techniques were carried out. It seems likely in the light of the work of Coombs (1968) that this clinical state may well represent an anaphylactoid syndrome. This can occur in both his Type I reaction which is 'reagindependent' and in his Type III reaction occurring after activation of complement by antigen-antibody complexes and the subsequent production of anaphylotoxin. McKay \& Margaretten (1967) suggest that the deposition of virus-antibody complexes in the walls of small vessels may be the trigger mechanism for acute disseminated intravascular coagulation. This causes clotting, thrombocytopenia and a haemorrhagic diathesis. This may be a major factor in the pathogenesis of haemorrhagic fever but also may play a part in diseases such as KFD where focal necrosis of the liver has been seen associated with central hepatic vein thrombosis especially in monkeys. Coombs (1968) states that in the Type II allergic reaction there may be a stimulating rather than a cytotoxic activity produced by complement and antibody to cell-membrane antigens. The consequences of this reaction may be very serious for cells because the lysosomal system is activated and the enzymes from the cells may be damaging (Fell, Coombs \& Dingle, 1966; Dingle, Fell \& Coombs, 1967). Coombs (1968) also suggests under his heading of microbial pathogenesis that many infecting micro-organisms would show very little pathogenicity on their own account or in an animal where allergic responses were completely suppressed; the pathogenicity, in fact, is due to the antigenicity of the organisms and their products and consequent tissue-damaging allergic reactions wherever the surviving organisms or their products happen to be. I would wholly support this concept but a great deal of work needs to be done to understand the problem clearly.

Connolly (1968) using the presence of antibody in the CSF to a previous virus infection (polio) has shown how it may be possible to measure antibody produced in the CNS rather than that which has 'leaked' across a blood-brain barrier of increased permeability. This technique was used to study the development of CSF antibody in two patients suffering from louping-ill encephalitis (Webb et al., 1968a) For exact diagnosis much more use should be made of the fact that antibodies to viruses rise much later in the CSF than in the blood.

As yet, nothing has been found that will destroy the arboviruses in vivo so one cannot approach therapy of this kind of CNS disease from this angle.

However, if the virus does act in some way as an antigen to which antibody is formed and then there is a brisk reaction between these two with inflammation and oedema and possibly stimulation of the lysosomal systems then it is reasonable to use steroids to keep the inflammation and oedema to the minimal. Steroids also have a stabilizing effect on the lysosomal systems. That oedema occurs is incontrovertible as papilloedema is often seen in severe cases and at necropsy one of the striking findings may be generalized oedema. I, therefore, believe in and have found very successful the giving of large doses of steroids as early as possible in the encephalitic phase. They should not be used before this because it is known that cortisone suppresses the production of interferon (Kilbourne, Smart \& Pokorny, 1961) which is the body's first line of defence against a virus infection. It should not be given as a preventive as this would almost certainly mean giving it at the time of the viraemia when interferon is being formed. Gleiser et al. (1961) have shown experimentally in monkeys infected with Venezuelan equine encephalitis (VEE) the beneficial effect of cortisone used at the beginning of the encephalitic phase. The course when given should be short, using a high dosage for 
the first 3-4 days and then tailing it off and finishing about the 10th day after initiation.

It is undoubtedly true that the CNS is infected very much more often than the clinical signs and symptoms would suggest. Recent experiments infecting mice with Langat virus peripherally show that the CNS has histopathological changes of encephalitis in $100 \%$ with only $33 \%$ showing symptoms of a CNS disturbance (Webb et al., 1968b). This is important when one considers the long term sequelae of virus infections and particularly those which have a predilection for the CNS. Following encephalitis there may be persistent coma, hemiplegia and persistence of other CNS signs which result from permanent damage to cells of the nervous system. However, symptoms and signs do develop later such as parkinsonism, alteration in personality, dementia and emotional lability which suggests chronic CNS disease. These changes may develop when no obvious clinical encephalitis has occurred. The persistence of high blood and CSF antibodies for a long time after infection suggests the continual stimulation of the immune mechanisms by virus particles. In the light of modern techniques it seems likely that persistence of virus in a form active antigenically if not infectiously may be causing some of these changes. This brings up the problem of latent infections with arboviruses. In our laboratory we isolated Langat virus from CNS tissue up to 36 days after infection from animals which were apparently healthy. Price (1966) has isolated KFD virus from mouse brains inoculated over 200 days previously. Anderson \& Goverdhan (personal communication 1966) have recovered KFD virus from a mouse brain inoculated 937 days previously. M. P. Chumakov has on several occasions isolated virus from the brain of patients infected up to 3 months previously with RSSE virus (Freymann, 1957). It is quite clear that many more viruses than previously thought have the capacity for latency and the arboviruses are among these. It is not only an important factor in the production of chronic CNS disease but it is also very important in relation to the survival of virus in nature. Reeves et al. (1958) have shown that Western equine encephalitis (WEE) virus can be recovered from birds up to 10 months after the original infection. Virus re-circulated in two birds at intervals of 198 and 234 days and similar findings in other animals have been recorded with St Louis encephalitis (SLE) virus (Webster \& Clow, 1936; Slavin, 1943) and with Japanese B encephalitis (JE) and VEE virus in hibernating bats (Corristan, LaMotte \& Smith, 1956; LaMctie, 1958). Thomas \& Eklund (1960) have shown that WEE virus can overwinter in experimentally infected garter snakes. These had the capacity to circulate virus at a high titre for long periods in the following spring from which normal mosquitoes were able to be infected and then successfully transmit the disease to chicks. Rehacek (1960) showed that tick-borne encephalitis virus survived in engorged larvae of Ixodes ricinus for 102 days under natural conditions of hibernation. This brings one on to the whole problem of why epidemics of arbovirus infections occur and how the virus may remain in an area between the active seasonal periods and how it may get introduced into a new area from other areas. Reeves (1961) puts forward the following hypothesis:

(1) Virus persists in unusually long-lived arthropod vectors in hibernation, aestivation, or diapause during unfavourable times and the vector retains its ability to transmit infection by bite at the end of such periods.

(2) Virus persists in the vector population through transovarian passage of infection from the female to future generations, and any stage of the vector may be infected and carry virus through unfavourable periods.

(3) There are undetected arthropod or metazoal vectors which carry virus through unfavourable periods with the currently recognized primary vectors functioning only during favourable periods.

(4) Vertebrate hosts may have chronic relapsing infections which will serve as sources of vector or vertebrate host infection following un favourable periods.

(5) Virus does not remain in many apparent endemic areas through unfavourable periods but is re-introduced annually or at longer intervals by migratory or wandering vertebrate hosts or vectors from other truly endemic areas.

He reviews each of the five suggestions and concludes that the most attractive hypotheses biologically are those based on persistence of the infectious agent in the primary vectors and vertebrate hosts of the summer cycle. That so many viruses can be shown to persist for such long periods of time in different conditions in so many different types of living cells should make one consider with considerably more interest the role of persistency or latency of viruses in diseases of human beings.

Zlotnik (1968) has shown that repeated inoculations of arboviruses into mice peripherally can produce a very dense astrocytosis in the brain. He also describes hypertrophy and excessive multiplication of the astrocytes as one of the earliest lesions in an arbovirus encephalitis. It occurs before the perivascular cuffing and neuronal degeneration. This effect of viruses stimulating growth of cells is of great interest and has been discussed by Webb (1967, 1968). It seems probable that under some conditions certain of the arboviruses can play a part in tumour formation (Tanaka \& Southam, 1962). 
One must not leave this field without considering the fascinating work now in progress on the transtadial and transovarial development of viruses in arthropods. This is excellently reviewed by Burgdorfer \& Varma (1967). That transovarial passage of tick-borne viruses can take place is certain, e.g. RSSE in Ixodes persulcatus (Chumakov, 1944; Singh, Pavri \& Anderson, 1963) in Haemaphysalis spinigera with KFD virus and many others. Chamberlain \& Sudia (1961) considered the possibility of transovarial transmissions of virus in mosquitoes but as yet there seems little evidence that any of the mosquito viruses do develop transovarially though the ovaries themselves and even an occasional egg may become infected. Chamberlain, Sudia \& Gogel (1964) working with SLE virus and Culex quinquefasciatus found that up to $92 \%$ of egg rafts laid after 8 days from ingesting an infected blood meal contained virus, mostly on the outer surface of the eggs. Occasionally it could be detected in the larva but not in the fully developed adult mosquitoes. However, Peleg (1965) has shown experimentally in the laboratory that in mosquito larvae infected with JE, SLE, Eastern equine encephalitis (EEE), WEE and West Nile (WN) virus, the virus developed transtadially and reached the salivary glands of females. These females were then able to transmit the virus to susceptible laboratory animals by biting. Evidence for this actually happening in nature has not been forthcoming as yet. Mussgay (1964) reviews the growth cycle of arboviruses in vertebrate and arthropod cells and Rehacek (1965) considers what determines the ability of an arthropod to become a biological vector. He postulates that this is determined genetically during its phylogenesis and that a 'gut barrier', shown by the inability of epithelial cells to support virus multiplication, may be responsible for the virus-vector specificity. It is not explained as yet why ticks can be infected with mosquito-borne viruses but mosquitoes cannot be infected with tick-borne viruses.

These are some of the vital problems to be solved in an investigation of an arbovirus encephalitis. As the old adage 'prevention is better than cure' is likely to be true for many years when dealing with this problem, it is of vital importance to study the basic problem of a virus in relation to its hosts, not only in animals and men, but also in the arthropods. Thomas (1963) studied the distribution of virus of WEE virus in the mosquito vector Culex tarsalis. LaMotte (1960) has done this with JE virus in the mosquitoes Culex quinquefasciatus and Culex pipiens. He studies its passage through the blood and various organs. He comments specifically on the high concentration found in nervous tissue in view of its neurotropic tendencies in man. There was frequently 100-1000 times more virus here than in larger organs. It is of particular interest to me that the multiplication of virus did not appear to cause cell damage. I am becoming convinced it is the development of immunological reactions to viruses that cause as much or more damage than virus multiplication itself. The similar survival of infected and non-infected mosquitoes indicates that the mosquito does not die as a result of virus infection and it seems that the mosquito tissues and this virus are well suited to a commensal existence. Possibly if the mosquito could produce antibodies against the virus this would not be the case!

As cytological and immunological staining techniques, refined sectioning and electron microscopy become more generally available the full life-cycle of these viruses in all their various hosts will be able to be worked out. The changes in their environmental conditions which are necessary for survival will be discovered and then it is likely that a way will be found to successfully break the virus cycle in nature and thus prevent a series of diseases for which no cure at the moment is available.

\section{References}

Alifanov, V L., Zakorkina, T.N., NetSkiI, G.I. \& Fedorov, V.G. (1961) Experimental data on the problem of the role of gamasid mites in the transmission of tick encephalitis virus and Omsk hemorrhagic fever. Med. Parazit. (Mosk.), 30, 24.

Bates, M. \& Roca-Garcia, M. (1946) The development of the virus of yellow fever in haemogogus mosquitoes. Amer. J. trop. Med. 26, 585.

BoNNE-WePSTER, J. \& BRUG, S.L. (1932) Subgenus stegomyia in Netherland India. Geneesk. T. Ned.-Ind. 72, 35.

BURGDORFER, W. \& VARMA, M.G.R. (1967) Trans-stadial and transovarial development of disease agents in arthropods. Ann. Rev. Entomol. 12, 347.

CASALS, J. (1957) The arthropod-borne group of animal viruses. Trans. N.Y. Acad. Sci. Series 2, 19, 219.

Casals, J. (1961) Procedures for identification of arthropodborne viruses. Bull. Wld Hlth Org. 24, 723.

Casals, J. (1963) New developments in the classification of arthropod-borne animal viruses. Proc. VII Internat. Congr. Trop. Med. Malaria, 11 (Part A), 13.

CASALS, J. \& BROWN, L.V. (1954) Haemagglutination with arthropod-borne viruses. J. exp. Med. 99, 429.

Catalogue (1968) Catalogue of the Arthropod-Borne Viruses of the World. U.S. Government Printing Office.

Chamberlain, R.W. \& Sudia, W.D. (1961) Mechanism of transmission of viruses by mosquitoes. Ann. Rev. Entomol. 6, 371.

Chamberlain, R.W., Sudia, W.D. \& Gogel, R.H. (1964) Studies on transovarial transmission of St Louis encephalitis virus by Culex quinquefasciatus Amer. J. Hyg. 80, 254.

Chumakov, M.P. (1944) Studies on virus encephalitides. VI. Transmission of tick-borne encephalitis to the offspring in Ixodidae ticks and the question of natural reservoirs of this infection. (In Russian). Med. Parazit. (Mosk.), 6, 38.

ConNolly, J.H. (1968) Additional data on measles virus antibody and antigen in subacute sclerosing panencephalitis. Neurology (Minneap.), 18, 87.

Coomвs, R.R.A. (1968) Immunopathology. Brit. med. J. 1, 597. 
Corristan, E.C., Lamotte, L.C. \& Smith, D.G. (1956) Susceptibility of bats to certain encephalitis viruses. Abstract Fed. Proc. (Federation of American Societies for Experimental Biology), 15 (i) (I).

Dingle, J.T., Fell, H.B. \& CoOmbs, R.R.A. (1967) The breakdown of embryonic cartilage and bone cultivated in the presence of complement-sufficient antiserum. II. Biochemical changes and the role of the lysosomal system. Int. Arch. Allergy, 31, 282.

Fell, H.B., Coombs, R.R.A. \& Dingle, J.T. (1966) The breakdown of embryonic (chick) cartilage and bone cultivated in the presence of complement-sufficient antiserum. I. Morphological changes, their reversibility and inhibition. Int. Arch. Allergy, 30, 146.

FreymanN, R. (1957) The virus encephalitides in the Soviet Union and in Central Europe. I. Spring-summer tick encephalitis. Reports of the Osteuropa-Institute of the Free University Berlin, 28, 34. Medical Series, Professor Dr med. Max Brandt.

GAJDUSEK, D.C. (1953) Acute infectious hemorrhagic fevers and myxotoxicoses in the Union of Soviet Socialist Republics. Med. Sci. Publ. Vol. 2. Walter Reed Army Medical Centre, Washington.

Gleiser, C.A., Gochenour, W.S., JR, Berge, T.O. \& TIGERTT, W.D. (1961) Studies on the virus of Venezuelan Equine encephalomyelitis: 1 . Modification by cortisone of the response of the central nervous system of macaca mulatta. J. Immunol. 87, 504.

HARRISON, J.L. (1958) Range of movement of some Malayan rats. J. Mammal. 39, 190.

HoogstraAl, H. \& Kaiser, M.N. (1961) Ticks from European-Asiatic birds migrating through Egypt into Africa. Science, 133, 277.

Hoogstraal, H., Kaiser, M.N., Traylor, M.A., Gaber, S. \& CuINDY, E. (1961) Ticks (Ixodides) on birds migrating from Africa to Europe and Asia. Bull. Wld Hlth Org. 24, 197.

Horstmann, D.M., McCollum, R.W. \& Mascola, A.D. (1954) Viraemia in human poliomyelitis. J. exp. Med. 99, 355.

HuRlbut, H.S. \& Thomas, J.I. (1960) The experimental host range of the arthropod-borne animal viruses in arthropods. Virology, 12, 391.

Kilbourne, E.D., Smart, K.M. \& Pokorny, B.A. (1961) Inhibition by cortisone of synthesis and action of interferon. Nature (Lond.), 190, 650.

LAMOTTE, L.C. (1958) Japanese B encephalitis in bats during simulated hibernation. Amer. J. Hyg. 67, 101.

LAMOTTE, L.C. (1960) Japanese B encephalitis virus in the organs of infected mosquitoes. Amer. J. Hyg. 72, 73.

LenNette, E.H. (1964) Diagnostic Procedures for Viral and Rickettsial Diseases, 3rd edn. American Public Health Association, New York.

McKaY, D.G. \& Margaretten, W. (1967) Disseminated intravascular coagulation in virus diseases. Arch. intern. Med. 120, 129.

MACNAMARA, F.N. (1955) Man as the Host of Yellow Fever Virus. Dissertation for M.D. Degree, University of Cambridge.

MUSSGAY, M. (1964) Growth cycle of arbo-viruses in vertebrate and arthropod cells. Prog. med. Virol. 6, 193.

PeleG, J. (1965) Infection of mosquito larvae by arboviruses. Amer. J. trop. Med. Hyg. 1, 158.

Price, W.H. (1966) Chronic disease and virus persistence in mice inoculated with Kyasanur Forest Disease virus. Virology, 29, 679.

ReEves, W.C. (1961) Overwintering of Arthropod-borne Viruses. Prog. med. Virol. 3, 59.

Reeves, W.C., Hutson, G.A., Bellamy, R.E. \& Scrivani, R.P. (1958) Chronic latent infections of birds with western equine encephalomyelitis virus. Proc. Soc. exp. Biol. (N.Y.). 97, 733.

REHACEK, J. (1960) Experimental hibernation of the tickborne encephalitis virus in engorged larvae of the tick Ixodes ricinus $L$. Acta virol. 4, 106.

ReHACEK, J. (1965) Development of animal viruses and Rickettsiae in ticks and mites. Ann. Rev. Entomol. 10, 1.

SEVER, J.L. (1962) Application of a microtechnique to viral serological investigations. J. Immunol. 88, 320.

Singh, K.R.P., PAVRI, K. \& ANDerson, C.R. (1963) Experimental trans-ovarial transmission of Kyasanur Forest Disease virus in Haemaphysalis spinigera. Nature (Lond.), 199, 513.

Slavin, H.B. (1943) Persistence of the virus of St Louis encephalitis in the central nervous system of mice for over 5 months. J. Bact. 46, 113.

SMith, C.E.G. (1962) Ticks and viruses. Symp. zool. Soc., Lond., No. 6, 199.

SMITH, C.E.G. (1964a) Factors in the transmission of virus infections from animals to man. The Scientific Basis of Medicine Annual Reviews, 8, 125.

SMITH, C.E.G. (1964b) Factors influencing the behaviour of viruses in their arthropodian hosts. 2nd Symposium of the British Society for Parasitology, 31 pp. Blackwell Scientific Publications, Oxford.

SMORODINTSEV, A.A. (1958) Tick-borne spring-summer encephalitis. Prog. med. Virol. 1, 400.

TANakA, S. \& Southam, C.M. (1962) Joint action of West Nile virus and chemical carcinogens in production of papillomas in mice. J. nat. Cancer Inst. 29, 711.

THOMAs, L.A. (1963) Distribution of the virus of western equine encephalomyelitis in the mosquito vector, Culex tarsalis. Amer. J. Hyg. 78, 150.

Thomas, L.A. \& EKLUND, C.M. (1960) Overwintering of western equine encephalomyelitis virus in experimentally infected garter snakes and transmission to mosquitoes Proc. Soc. exp. Biol. (N.Y.), 105, 52.

Walker, A.S., Meyers, E., WOOdhill, A.R. \& McCulloch, R.N. (1942) Dengue fever. Med. J. Aust. 2, 223.

WeBB, H.E. (1967) Viruses and the neuroglia with special reference to scrapie, kuru and disseminated sclerosis. Proc. roy. Soc. Med. 60, 698.

WeBb, H.E. (1968) Factors in the host-virus relationship which may affect the course of an infection. Brit. med.J.4, 684.

WebB, H.E. \& Burston, J. (1966) Clinical and pathological observations with special reference to the nervous system in Macaca radiata infected with Kyasanur Forest Disease virus. Trans. roy. Soc. trop. Med. Hyg. 60, 325.

WebB, H.E. \& Chatterjea, J.B. (1962) Clinico-pathological observations on monkeys infected with Kyasanur Forest Disease virus, with special reference to the haemopoietic system. Brit. J. Haemat. 8, 401.

Webb, H.E., Connolly, J.H., Kane, F.F., O'Reilly, K.J. \& SIMPSON, D.I.H. (1968a) Laboratory infections with louping-ill with associated encephalitis. Lancet, ii, 255.

Webb, H.E. \& LaKshmana RaO, R. (1961) Kyasanur Forest Disease: a general clinical study in which some cases with neurological complications were observed. Trans. roy. Soc. trop. Med. Hyg. 55, 284.

WebB, H.E. \& SMith, C.E.G. (1966) Relation of immune response to development of central nervous system lesions in virus infections of man. Brit. med. J. 2, 1179.

Webb, H.E., Wetherley-Mein, G., Smith, C.E.G. \& McMAHON, D. (1966) Leukaemia and neoplastic processes treated with Langat and Kyasanur Forest Disease viruses: a clinical and laboratory study of 28 patients. Brit. med. $J$. $1,258$.

Webi, H.E., Wight, D.G.D., Platt, G.S. \& Smith, C.E.G. (1968b) Langat virus encephalitis in mice. I. The effect of 
the administration of specific antiserum. J. Hyg. (Camb.), 66, 343.

WebB, H.E., Wight, D.G.D., Wiernik, G., Platt, G.S. \& SMITH, C.E.G. (1968c) Langat virus encephalitis in mice. II. The effect of irradiation. J. Hyg. (Camb.), 66, 355.

Webster, L.T. \& Clow, A.D. (1936) Experimental encephalitis (St Louis type) in mice with high inborn resistance.
J. exp. Med. 63, 827.

WoRK, T.H. \& Trafido, H. (1957) Kyasanur Forest Disease: a new virus disease in India. Ind. J. med. Sci. 11, 340.

ZLOTNIK, I. (1968) Reaction of astrocytes to acute virus infections of the central nervous system. Brit. J. exp. Path. 49, 555. 